\title{
Adaptation to the Climate Change Impact through Community Participation on Customary Land Use
}

\author{
Zaflis Zaim $^{1, *}$ Imam Buchori $^{2}$ \\ ${ }^{1}$ Urban and Regional Planning Department, Universitas Islam Riau Indonesia \\ ${ }^{2}$ Urban and Regional Planning Department, Universitas Diponegoro Semarang .
}

* Corresponding author : zaflis@eng.uir.ac.id

Received: Jan 1, 2019; Accepted: Mar 30, 2019.

DOI: 10.25299/jgeet.2019.4.2.2777

\begin{abstract}
Climate Change and global warming have brought some policy to reduce the impacts by adaptation and mitigation strategies. One adaptation strategy is to increase land use size in agriculture area base on community participation. On the other hand, sustainable development needs cooperation mainly on common investment. The aim of the study is to identify the land utilization process, role model and level of participation on customary land. We use observation and deep interview method to analyze this study. The result shows that the customary land utilization process has realized through public deliberation with local Fig.s. The agriculture programs operated with Wanatani concept or agro-forestry by housewives where multi-level strategy is mutually beneficial. Around 30 housewives have been participating in producing agriculture products, i.e., coffee, milk candy, palm sugar, and ginger powder. The level of participation especially for female farmers at RW 01, which shows a percentage of $16.6 \%$ Generally, community participation has encouraged the gotong-royong model while has to contribute in their time, tools and materials to develop the communal shed. In conclusion, the land tenure system has taken with sharing benefits between local government $\&$ farmers. The customary tenure has recognized as one of the tenure systems in Indonesia, especially on Adat land management.
\end{abstract}

Keywords: Climate Change, Development, Participation, Adat Land, Investment.

\section{Introduction}

\subsection{Background}

It has been important in the issues concerning climate change and global warming caused by the increasing concentration of Greenhouse Gases (GHG) in the atmosphere in every country. It has been producing the volume of sea and sea level increase significantly every year (Bellard et al, 2013). The phenomenon also has been gave an impact such as inundation at many coastal city like Semarang (Buchori et al, 2018).

On the other hand, Semarang Regency contributed around 1.7 million tons of CO2e in 2009, and it was predicted to increase to 2.9 million tons of CO2e by 2020 (KLH, 2009). Mostly, the emissions are from the use of fossil energy for electricity and transportation with a total contribution of about $49.77 \%$ of the total emissions. Fig. 1 and 2 describes greenhouse gases emission projection from government and community activity.

Indonesia seeks to implement a policy of reducing Greenhouse Gas emissions by $26 \%$ from business as usual through the implementation of Presidential Regulation Number 61/2011. According to the regulation, the Government of Semarang Regency is required to reduce GHG emissions through mitigation efforts. In the aspect of mitigation, the planning of the action program is expected to contribute to reducing emissions by $3.71 \%$ by 2020 .

Climate change mitigation is an effort to reduce the production of Greenhouse Gases to minimize global warming. Meanwhile, the adaptation of climate change is an effort to adjust to climate change aimed at reducing risk and increasing resilience. An integrated climate strategy implemented through an action plan that is integrated into the development planning process, including expanding the area of land cover; carry out conservation \& management of water resources; and management of domestic and industrial wastes (BLH, 2014).

The activities conducted at the effort to expand the area of land cover include planting trees suited to the climate $\&$ humidity conditions in the region. Domestic waste management through the development of biogas facilities from livestock manure, building the septic tank and producing organic fertilizer. Meanwhile, the conservation \& management of water resource is performed through the construction of reservoirs, infiltration wells, and water reservoirs. These activities are conducted through community efforts based on community participation, especially in 5 villages, including Lerep, Pagarsari, Branjang, Gogik, and Nyatnyono. Through 
the joint commitment, community participation has been encouraged and significantly improved in addressing issues and reducing the impact of climate change by utilizing private, state-owned (plantations) and village-owned lands, among others: allocated land (Bengkok land), village-owned properties, and community forests.

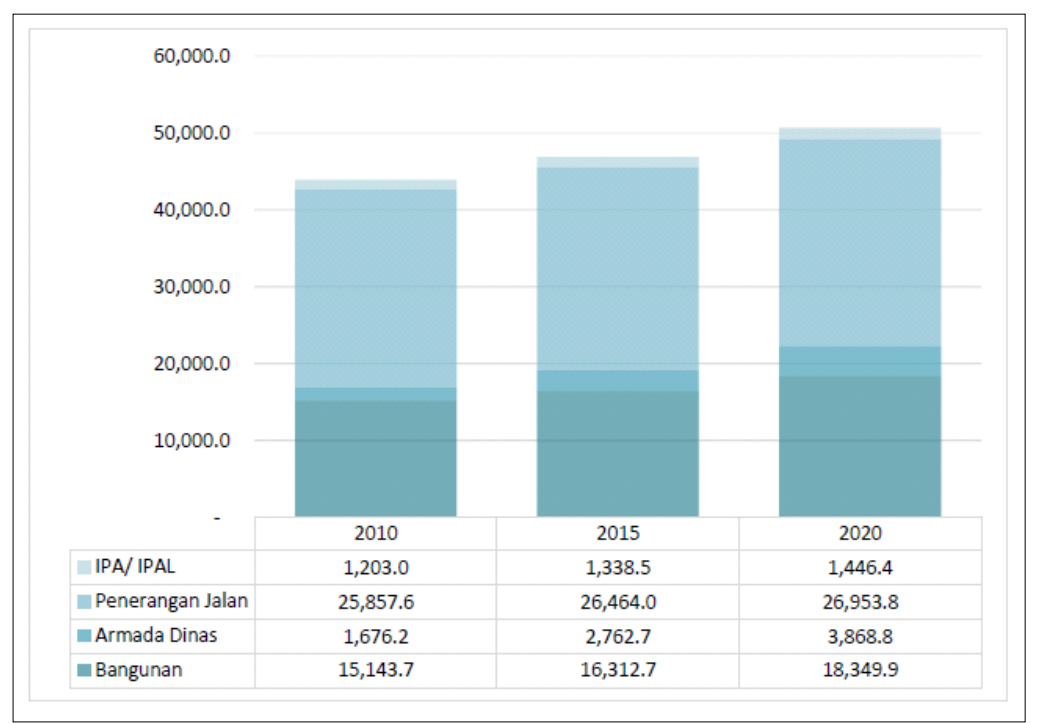

Fig 1. Greenhouse Gases Emission Projection from Government Activities, the year 2010-2020

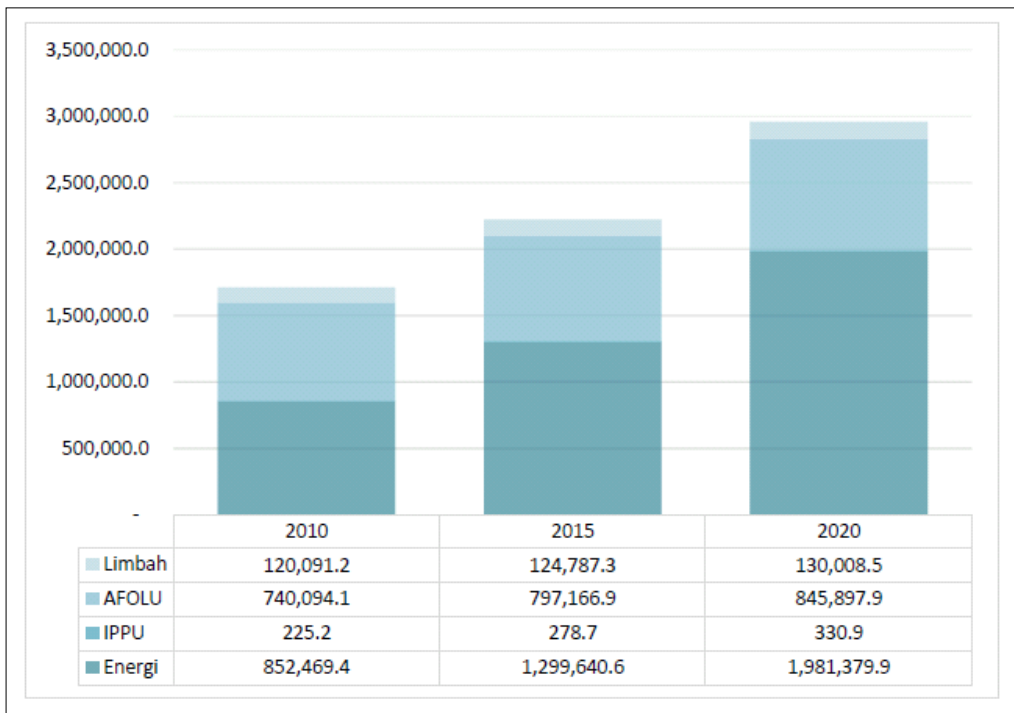

Fig 2. Greenhouse Gases Emission Projection from Community Activities, the year 2010-2020 (Source: Integrated Climate Change Strategy Semarang Regency, 2014)

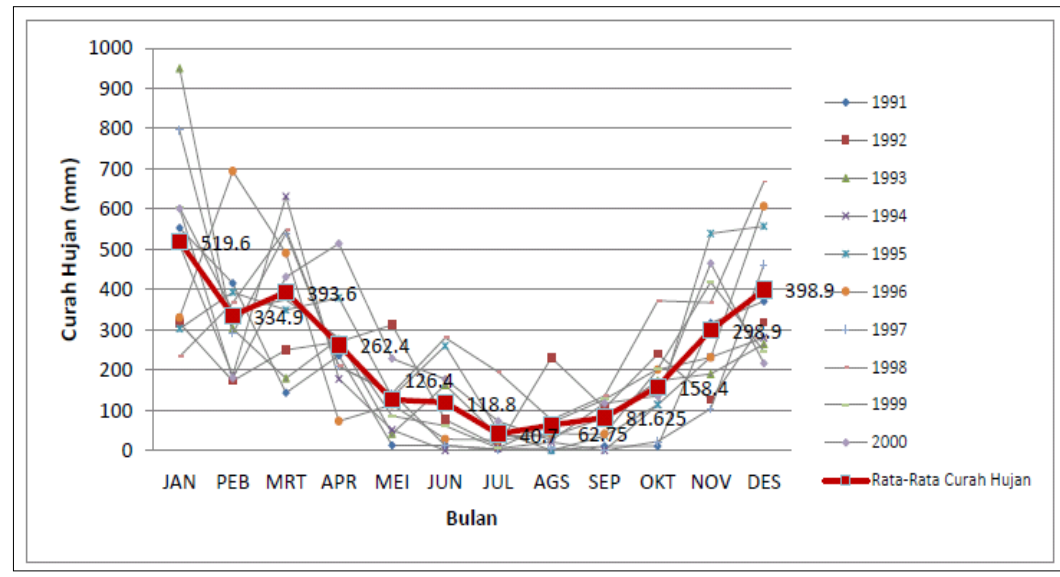

Fig.3. Monthly Rainfall 1991 to 2000 at Semarang Regency

(Source: Processed from Monthly Rainfall Data - Distanbunhut Semarang Regency, 2014). 


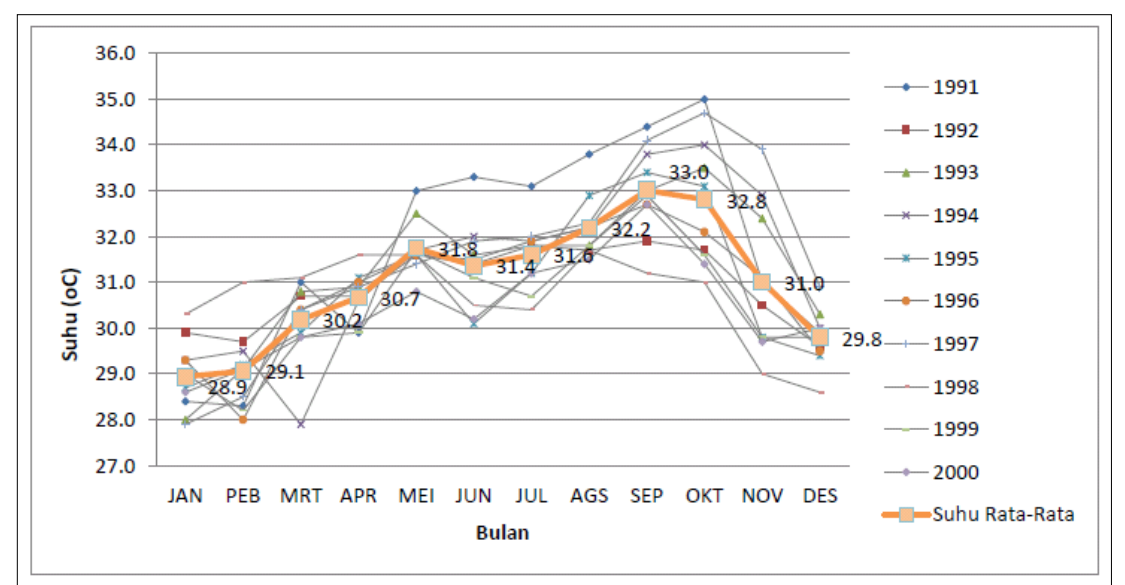

Fig.4. Monthly Temperature Average, the year 1991 to 2000 at Semarang Regency.

(Source: Processed from Monthly Temperature Average - Distanbunhut Semarang Regency, 2014)

\subsection{Objectives and Focus of the Research}

This study aims to identify the process of land use, especially for village-owned land, to map the participation model and measure the level of community participation that develops during the village-owned land planning \& utilization process. Village-owned land as the object of research was focused on the distribution of allocated land (Bengkok land).

The utilization of village-owned land is inseparable from government policies and programs in adapting and reducing the impact of climate change, especially in Semarang Regency. The study was centralized at Lerep village as one of the villages that realizes the climate changes mitigation programs. There are 2 kind of adat land such as Bondo desa and bengkok land (see Fig. 5).

This research will focus on: settlement problem that encouraged participation, number of local Fig.s who have actively communicated to the participation process, the duties or tasks of the Fig., type of land use and the allocation of village-owned land, the periodization of the land planning process, the type of plants in mitigation/adaptation programs, the developed agricultural or livestock derivative products. The object or focus of this research can develop according to the facts and conditions at the research location.

\section{Literature Review}

\subsection{Community Participation and Planning Process}

Community participation can be defined as the participation of all or some members of society in solving problems that occur in the community life (Indonesia Dictionary, 2001). Glass (1979) defined citizen participation as "providing citizens with opportunities to take part in governmental decision or planning processes". Community participation is an element in the planning process so that it can be seen from the reality that there is a very relationship between community participation and the planning process.

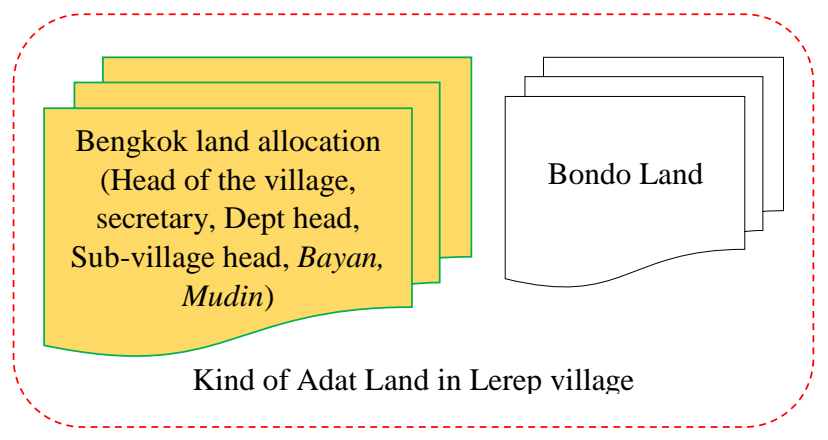

Fig.5. Kind of Adat Land in Lerep Village and Research Focus

Planning requires input that, on the one hand, to success the process, and on the other hand, it can not provide other inputs (Day, 1997). The weaknesses in terms of resources (place, energy \& money) and time limitations (deadline) are common in the planning process that can reduce the effectiveness of community participation (Day, 1997). Transactive planning finds the knowledge transformation resulted from the communication between professionals and community members in action (Friedman, 1973). Thus, collective learning is a process conducted with the community by learning from each other by listening, respecting, and being open to each other.

Community participation in the planning process can provide benefits for the community and local government. Therefore, Burby (1997) states that the clarity and specific management of the growth of a country growth can improve the quality of urban planning. A study conducted by Dawkins \& Nelson (2003) proved the existence of the relationship between growth and development management programs. They found that cities with interesting growth management programs would attract new construction activities to be more frequently (Dawkins and Nelson, 2003).

The planners must also target stakeholders and groups that have some interests so that they are base on contributions they can make during the planning process. Some theories explain opinions with the techniques or methods used are emphasized to get 
attention and increase the level of community participation. A scientific group has also proven that the methods used by the planners in choosing the community participation processes (e.g. hearing, open house, surveys) will also have some effect on the level of participation (Brody, Godschalk and Burby, 2003).

\subsection{The Required Parties to Participate}

A component of a community chooses to participate on different issues or problems. Groups with different backgrounds may choose to participate at different stages of the process, especially for big projects. So that the number and type of participants can change during the planning process (Sanoff, 2000). The community is also not pleased or finds difficulties to accept a decision made by someone. Therefore, to present an agreement, they must feel that they have an idea or to take part in the decisionmaking process (Fisher \& Ury, 1981). This is cause the characteristics of each person are different based on their natural conditions.

The public or the community prefers to participate in the process if they can see how their inputs or suggestions can change a decision or if the decision can affect their lives in the present and the future (Brody, Godschalk and Burby, 2003). According to Creighton (1994 in Sanoff), people also choose to participate if:

a. They perceive themselves as being influenced by an issue because of a threat that may present or of the benefits of the proposed facility;

b. They have economic interests, especially for the results of a decision;

c. They need protection to get increased access to the use of a facility or public service and other conditions or motivations.

The community will participate according to their level of expertise, interest or intention in a condition and life problem (Maier, 2010). These are becoming a variable level of involvement that depends on differences in technical expertise, roles in society, and willingness to provide time and energy. So, the number, composition or type of participants can change $\&$ differ during the decision making and the planning processes (Creighton, 1994; Sanoff, 2000). The number of people involved in the direct process can also influence the duration of the process (Stewart $\&$ Sinclair, 2007).

\subsection{Land Tenure System}

Land tenure generally refers to an understanding of land position so that someone can use land under a legal utilization system which regulated in government regulation in the community recognized by the state. Below are some definitions of land tenure from some sources:
"Arrangement or right that allow a person or a community to use specific pieces of land and associated resources in a certain period and for particular purposes" (Choudhury and Jansen, 1997).

"Compromises the habitual and /or legal rights that individuals or groups have to land and the resulting social relationships between the numbers in society" (Werhmann, in Rudiarto 2006).

"A land tenure system consists of the organized and established institutional arrangements in society that govern how land \& resources are allocated, used and enjoyed" (Nichols, 1993).

From the definitions above, there are some elements related to land tenure, including regulation, land access, Iand utilization control, ownership, land utilization type and social relation in the community. The combination of the elements forms the land tenure system, which is an interpretation of ownership of property in general. Land tenure system then creates a condition where available land is connected with a physical object and was realized as construction on the owned property or asset. The strength of a land status depends on the certainty of land use. Therefore, land tenure is very vital on planning and development of land in a location.

The strength of land status depends on the legal and social aspect of someone in utilizing the land. The legal aspect contains legal recognition of land ownership while the social aspect contains reality which produces the community's recognition of the land. Both aspects can reinforce the position of land ownership, so that tenure security is also very important in land planning and development. Legal recognition and the fact of land status also demand thoughts, concept, and strategy for land legitimacy or legalization (Rudiarto, 2006). Legalization will strengthen and give trust to a local community in planning, management, and optimization of land use. According to Payne (2002), there are five types of land tenure system:

a. Customary land. The system considers land to be community asset managed and protected for current and future generations. The allocations, transfers, usages are determined by a community leader.

b. Private tenure. The system views individual and gives complete freedom in owning and managing their land asset. The condition was concentrated in the urban area.

c. Public tenure. The system exists due to reaction to a limitation of individual ownership and grows in public needs.

d. Religious tenure. The system is often found in Islamic countries where charity agencies are appointed to manage certain lands.

e. Non-formal tenure. The system is land ownership which is closely related to legality and illegality. The system is often found in lower social class society. 


\section{Research Method.}

\subsection{Research Tool and Material}

This study used secondary and primary data in the form of maps, interviews, observation or photo documentation. The secondary data comes from Village Office of Lerep, BPS/statistical center bureau, Public works Agency and Environmental Board (BLH) of Semarang Regency. To support the mapping, the ArcGIS application, mobile mapper and remote sensing drone were used as the inputs for research data. Other tools were used the interview guides, recording devices, and cameras.

\subsection{Analysis}

The research approach was conducted by using an observation method on the observed object according to the research objectives. Descriptive-qualitative analysis techniques explain the level of participation and the planning process of the utilization of villageowned land. Meanwhile, the community participation model is explained through the chart of the land planning process along with a description of the duties/responsibilities of each key personnel or local Fig.s who play some roles. The interview conducted with the informants was used to get a more detailed explanation of environmental conditions and phenomena. Meanwhile, the spatial data overlay was used for obtaining the overview of land development from the early until the recent period.

\section{Results}

Lerep Village covers an area of 682.24 hectares (Bintari \& FoE, 2012). The results of observation showed that the dominant land use functioned as agricultural land with the biggest use for plantations or fields, covering the total area of 166.18 hectares $(24.3 \%$, followed by the state-owned plantation $(22.2 \%$, and irrigated rice fields $(19.9 \%$. While the area of non-agricultural land is 183.11 hectares or $26.8 \%$ From the results of intervi ews \& observations, it is known that Lerep Village has widely distributed Village-owned properties \& lands as customary lands. Planning and utilization of land are under the authority of the village head and his sub-ordinates elected by the community. The distribution $\&$ area of land use in Lerep Village can be sawed in the Fig. 6 and 7 below.

Before 2006, most of these lands were used by residents for rainfed lowland agriculture and less productive dry land (Results of interview Sgt, 2018). The shift in the use of village-owned land began in early 2006 when a health care officer in West Ungaran saw environmental hygiene problems, especially for residential areas. At that time, the healthcare officer assessed the existence of unhealthy residential problems due to the location of livestock pens close to community residential area. Besides, livestock manure produces a bad smell, cleanliness problems, and poor sanitation. Therefore, the healthcare officer began taking steps to communicate and socialize with the village head by inviting local Fig.s to find solutions to the environmental problems in the community settlements. The communication, coordination and community consultation processes can be seen in the Fig. 8 below.

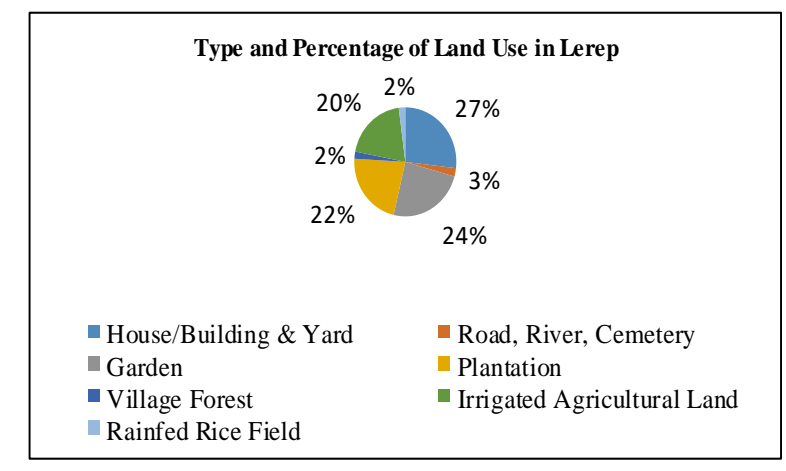

Fig 6. Type and Size of Land Use in Lerep.

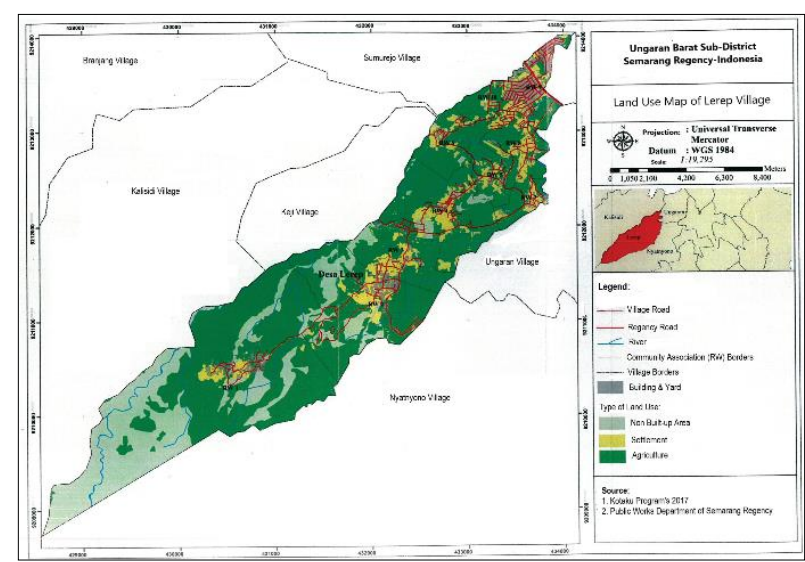

Fig. 7. Map of Land Use in Lerep Village (Source. Mitigation Risk Disaster Based on Community, DPU and MCl 2018)

Community participation began to be conducted intensively and reached a peak through deliberation at the sub-village level. This activity was pioneered by the health care officer and driven by the role of village officials. Given the existence of environmental problems above, the main objective of sub-village deliberation was to discuss the issues of cleanliness and environmental health due to the presence of livestock pens in every house. The final process of the deliberation resulted in an agreement between the community and the village officials to build a shared cattle shed on the allocated land (Bengkok land).

The results of the community meeting/deliberation also decided the plan to use the allocated land, especially for Bengkok bayan, as the location for the construction of livestock pens. Considering that there were no people assigned in Indrokilo Sub-Village and assigned as Bayan (the vice head of sub-village), the village head wanted to allocate Bengkok-Bayan land for the development plan. From the results of the interview, it knows that the right of Bengkok-Bayan 
land management in Lerep Village is on the authority of the village head (Interview with Sgt and Atn, 2018). The result of the agreement made between the community, healthcare officer and village officials was a recommendation that every cattle breeder can relocate their livestock pens to the communal livestock pens.

The construction process of communal livestock pens was started in late 2007 through cooperation, both in terms of labor, tools and times. After constructing the communal livestock pens, the village officials asked the residents to move their cattle to the agreed location and to be relatively far from their houses. The condition of communal sheds can be seen in Fig. 11. The role model of every local Fig. can be seen in the Fig. 9.

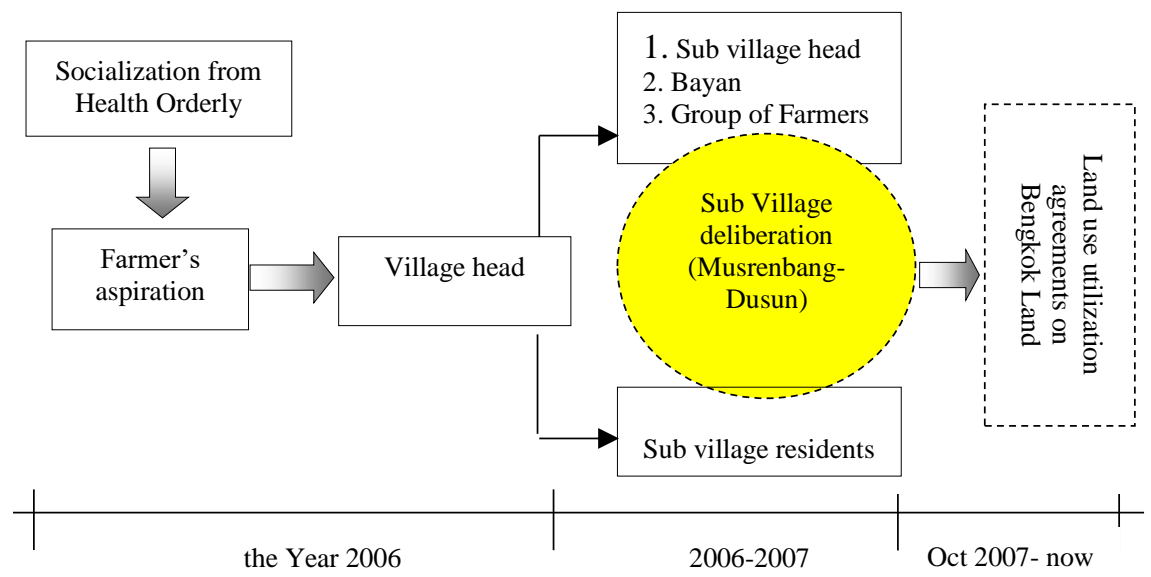

Fig 8: Initial Process of Proposal \& the Parties Involved in Discussion of Bengkok Land Utilization Planning

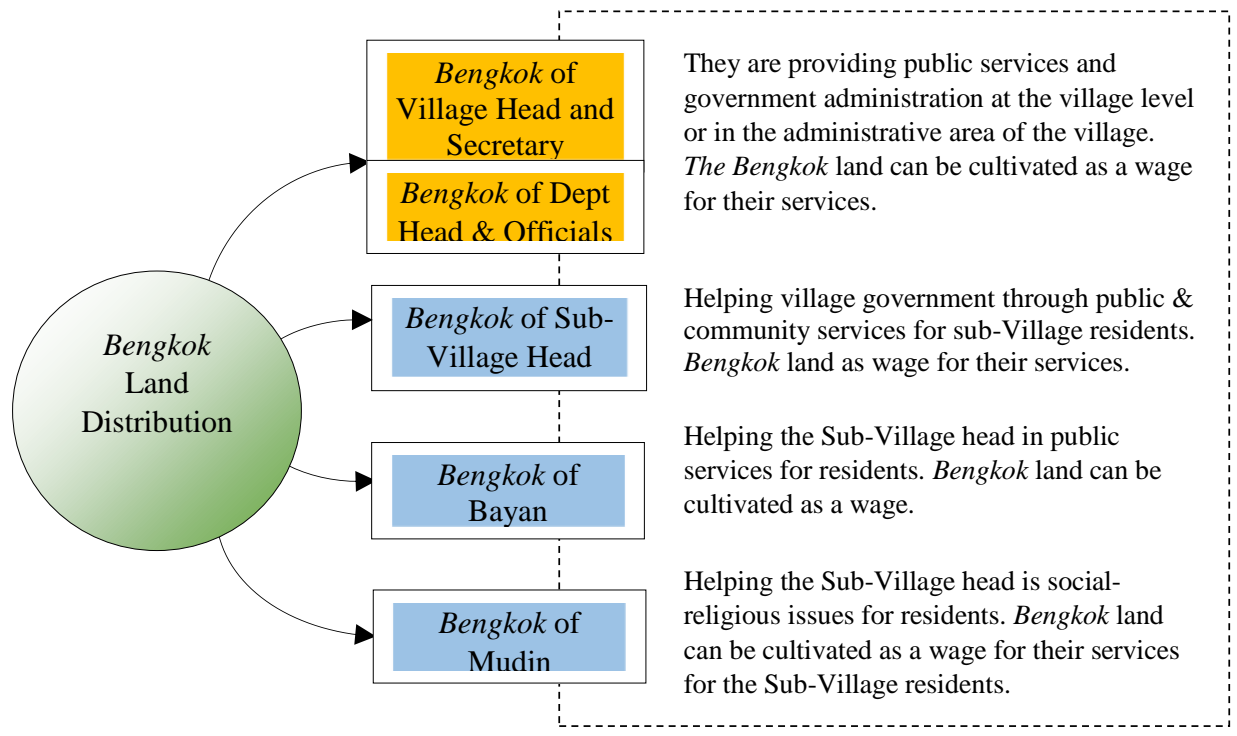

Fig 9. Distribution of Bengkok Land Management for Village \& Sub-Village Officials \& Their Obligations

Furthermore, the assistance received from the local government was in the form of biogas tank facilities for processing manure into gas for household needs. At almost the same time, the domestic and foreign NGOs also assisted in the form of plant seeds planted on village-owned land, community forests and other types of land. This effort was intended to reduce the impacts of climate change, especially in Semarang Regency, while encouraging the community participation in increasing the area of land cover. Types of plant seeds provided by NGOs to villagers include Albizia Chinensis, Clove, Mahogany, Avocado, Durian, Arenga pinnata, Longan, and Coffee (Interview with Bintari Staff, 2017). Based on the topography, rainfall and climate data in the Fig. 3 and 4, the types of plants were suitable to be planted in locations with altitudes of more than 600 meters above sea level 
with fairly cold temperatures. The results of the topography mapping can be seen in the Fig. 10.

Based on observations, the processed agricultural products include palm sugar, coffee powder, milk candy, soap, crackers, ginger powder, boiled Aren nut, honey, cloves, Albizia Chinensis powder, and cow's milk (see Fig. 13). In addition to reducing the impact of climate change, the types of crops above also provided added value for improving the household economy compared to paddy.

Based on the results of interviews, it was found that there were 180 families in the $R W-01$ (community association) of Lerep Village with a total of $4 R T$ (neighborhood association). Mostly, the residents work as farmers of horticultural crops, perennial crops, and breeders (cows \& sheep). In addition to agricultural products, farmers also make processed products from plants grown in the village. The farmers divided into two groups, namely: Wanita Tani and Ngudi Makmur. Wanita Tani is a group of female farmers with 22 active member of 30 members, while Ngudi Makmur is a farmer group consisting of 32 male farmers.

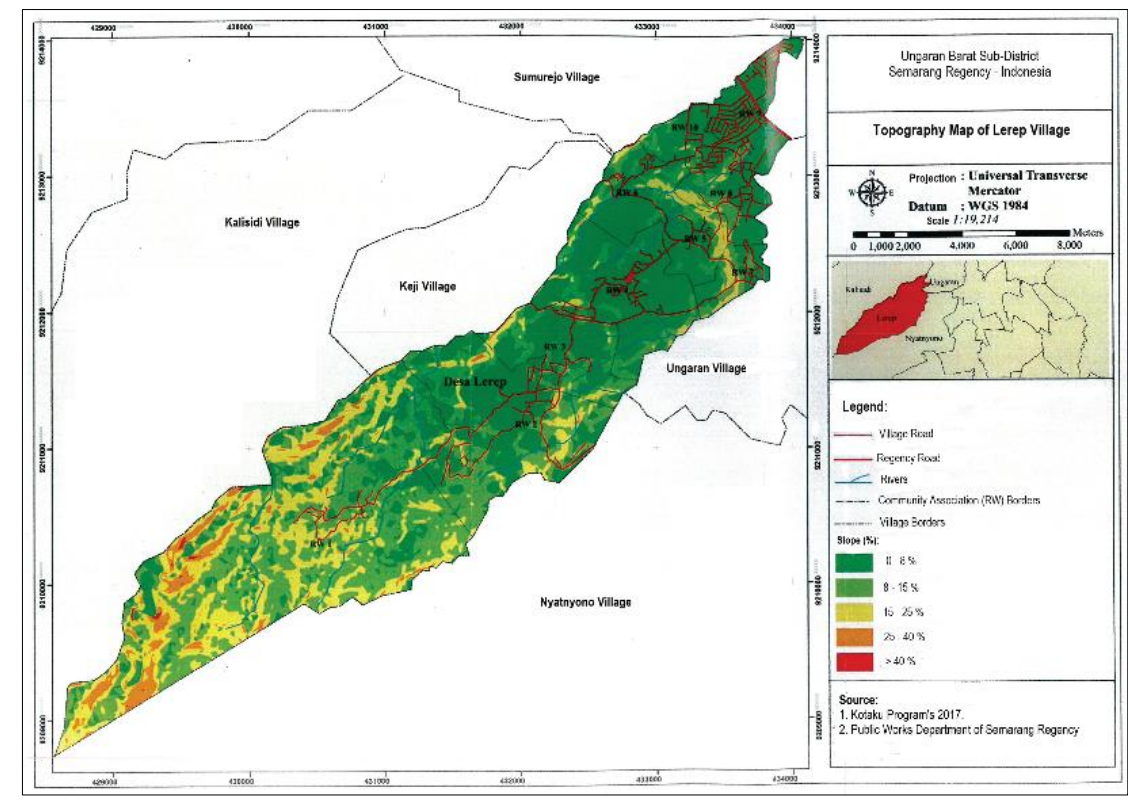

Fig 10. Map of Topography in Lerep Village.

(Source: Mitigation Risk Disaster Base on Community, DPU and MCI 2018)
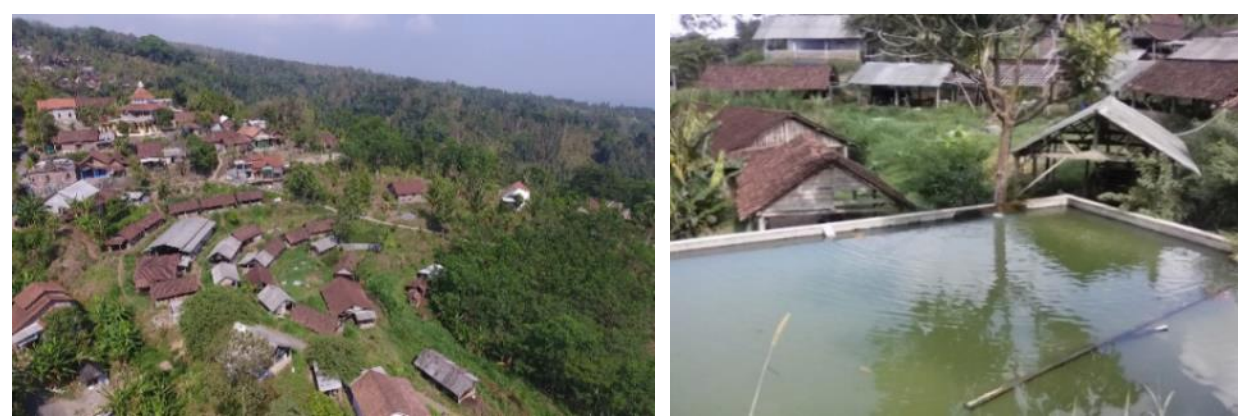

Fig 11. Land Use Condition and Communal Sheds

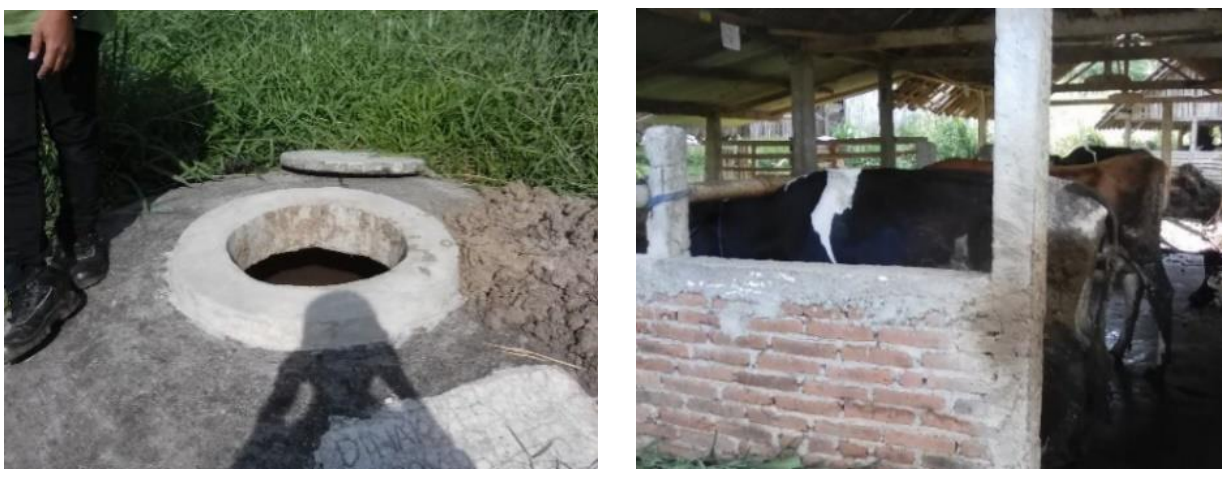

Fig 12. Tank Installation of Biogas \& Communal Sheds 

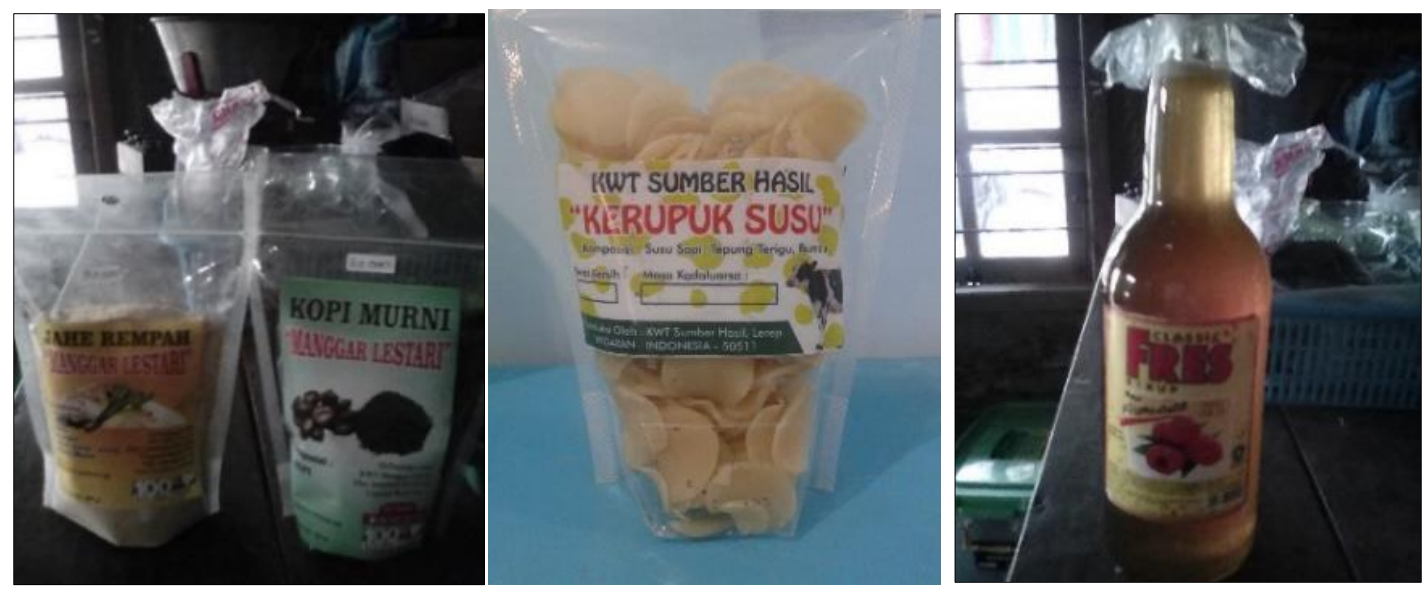

Fig 13. Coffee Product, Ginger, Crackers, and Honey from Agriculture Farm

Table 1. Name, Number of Farmers Group \& Their Activity

\begin{tabular}{|c|c|c|c|}
\hline No & Farmers Group Name & Focus/Activities & $\begin{array}{l}\text { Number of Group } \\
\text { Members (person) }\end{array}$ \\
\hline 1 & Ngudi Makmur & Livestock & 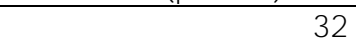 \\
\hline 2 & Mangger Lestari & Products of agriculture farm. & 30 \\
\hline & & Total & 62 \\
\hline
\end{tabular}

The allocated land is used for, among others, agricultural activities, cattle breeding, and social facilities, such as education and healthcare facilities. Also, there are also sanitation facilities built, such as biogas tanks or wells that process cow manure from communal sheds into gases (see Fig. 12). The gas products are then supplied to five houses around the allocated land. At the initial stage of operation, it was known that the Biogas tanks could function properly. However, there were some constraints in the operation of the installation such as the high costs of maintenance, material, expert \& technical maintenance of the installation.

In general, the management of the village-owned land requires agreement, memorandum of understanding and commitment during its utilization and requires the clarity of collective investment patterns from the community. Therefore, it is not surprising that investment factors play a major role in sustainable land management. Hartshon, in Adnyana (2002) argues that land investment encourages land use change for several reasons: economic/profit motives; preferences; comfort; values \& perceptions (Hartshon., et al. 1992). Village-owned land in the form of crooked land certainly has a value in the form of a permanent position on the status of the land, so that it affects the perception of the community in its utilization or management.

The number of farmers who are actively involved in managing village-owned land and their processed products can be sawed in the table 1 below. The table also explains the level of community participation in village-owned land management especially for RW 01, which shows a percentage of $16.6 \%$ for female farmers).

\section{Discussion}

In general, the management of the village-owned land requires agreement, memorandum of understanding and commitment during its utilization and requires the clarity of collective investment patterns from the community. Therefore, sustainable investment in village land management is influenced by factors: technical, physical, socio-economic, cultural and institutional factors. However, the actual influence of these factors differs in time and space (Nyanga, Aad Kessler \& Albino; 2016). Regarding socio-economic factors, other researchers showed the influence of motivation to invest in land management namely: personal characteristics, availability of resources, participation in past programs, conditions \& market access and development strategies (Adimassu et al., 2012; Bamlaku, 2011; Kessler, 2006; Paudel and Thapa, 2004; Tenge at al., 2004).

The personal characteristics of farmers in terms of the education level of the head of the household are urgent and influential on land conservation in Nepal (Paudel and Thapa, 2004). Whereas in Ethiopia, the characteristic is a combination between several factors, such as the contribution of resources, the experience of the head of the household, knowledge, and access to information that explains the decision of farmers for how much $\&$ where to invest in land management (Adimassu et al, 2012). Therefore, the key socio-economic factors for investment patterns in the land cultivation system, need to get more attention through research.

Land conversion occurs in unplanned settlements, especially the use of customary land in Lerep village which has been less productive and has changed its function to become more productive land for 
agricultural activities, livestock and social activities. Dynamics and variations in agricultural activities are pursued through collective investment efforts from farmers who are driven by climate change mitigation \& adaptation programs. However, the low level of farmer participation in investing in village land, limited information \& funds and the stagnation of sanitation programs require observation and deepening of studies using appropriate methods. On the other hand, the existing land management investment theories are only suitable for investment in private land. According to literature review and observation, the customary land is the state-owned land with usufructuary status, but not all farmers who have management rights beside the breeders. This condition have decrease a chance to other residents (farmers) on Bengkok utilization. So, it was semipublic on management system while actualized.

\section{Conclusion}

The climate change mitigation $\&$ adaptation programs have encouraged the growth of community participation via the use of village-owned land. Although the level of participation that has developed is not high enough, the agricultural \& livestock activities with agroforestry systems with adjustments to climate conditions and crop types have been able to increase the income of the community in Lerep.

This research only focused on the utilization and management system of village-owned land. Therefore, the researchers suggested that observations on the level of community participation in climate change mitigation or adaptation programs can also observe in other types of land use, especially on the plantation and community forests as the widest land in this village. Also, the influencing factors of the investment in land management in the utilization of villageowned land need to be a review.

The scope of the study area can be expanded to others sub-district from Lerep village. This intended to achieve and develop to land information system in the land parcel that is more informative and integrated between the government institutions. The spatial data system will give some advantages on land registration, status transformation, permit extension, spatial planning process up to legalization phase.

\section{Acknowledgements}

We say thanks LPDP (Educational Fund Management Agency) for the research cost assistance, the rector of Universitas Islam Riau and Semarang Regency Government for the survey and permission. We also would like to thank farmers group, research assistant and local actors for their contribution and attentions.

\section{References}

Adnyana, I Ketut Puspa, 2002. Perubahan Pemanfaatan Ruang dalam Perspektif Masyarakat Adat Bali, Studi Kasus Padangsambian Denpasar, Disertasi-tidak dipublikasi, PPS-Universitas Gadjah Mada, Yogyakarta.

Adimassu, Z., Kessler, C.A., Hengsdijk, H., 2012. Exploring determinants of farmers'investments in land management in the Central Rift Valley of Ethiopia., J.Applied Geography. 35, 191-198.

Bamlaku, A., 2011. The impact of poverty, tenure security \& risk on sustainable land management strategies in northcentral Ethiopia: Analysis across three agro-ecological Zones, J. Sustain. Dev. Afr. 13, 227-240.

Bellard, C. Leclerc, F. Courchamp., 2013. Potential impact of sea level rise on the French Islands worldwide, Nat. Conserv. 5, 75-86.

Bintari dan Friend of Earth., 2012. Kerangka Konsep Pendidikan Lingkungan Hidup: Studi Kasus Masyarakat Indrokilo Desa Lerep Kecamatan Ungaran Barat, Yayasan Bina Karta Lestari, Semarang, p.19.

Brody, S., Godschalk, D., and Burby, R., 2003. Mandating Citizen Participation in Plan Making Six Strategic Planning Choices; APA Journal, 69 (3), 245- 262.

Buchori, I., A.Sugiri, Mussadun et al., 2018. A predictive model to assess spatial planning in addressing hydrometeorological hazards: A case study of Semarang City, Indonesia, International Journal of Disaster Risk Reduction, 27, 415-426.

Burby, R.J., and P.J. May., 1997. Making Governments Plan: State Experiments in Managing Land Use, Baltimore: Johns Hopkins University Press.

Choudhury, K and Jansen Louisa J.M., 1997. Terminology for Integrated Resources Planning and Management, FAO, Rome.

Day, D., 1997. Citizen Participation in the Planning Process: An Essentially Contested Concept, Journal of Planning Literature, 11(3), 421-433.

Fisher, R., and Ury, W., 1981. Getting to Yes, Houghton Mifflin Company Boston, USA.

Friedmann, J., 1973. Retracking America. A Theory of Transactive Planning, Anchor Press/Doubleday. Garden City, NY

Dawkins, C. J., and Nelson, A. C., 2003. State Growth Management Programs and Central City Revitalization, Journal of the American Planning Association. 69(4): 381396.

Glass, J.J., 1979. Citizen Participation in planning: The relationship between objectives and techniques, Journal of the American Planning Association, 45, pp.180-189.

Kessler, C.A., 2006. Decisive key-factors influencing farm households' Soil and Water conservation Investments, J.Appl. Geogr. 26, 40-60.

Maier, Karel., 2010. Citizen Participation in Planning: Climbing a Ladder? Publisher: Routledge. http://dx.doi.org/10.1080/713666506.

Nichols, S., 1993. Land Registration: Managing Information for Land Administration., PhD Dissertation, Department of Surveying Engineering, Technical Report No.168., University of New Brunswick, Fredericton, New Brunswick, Canada., 340pp.

Nyanga, Aad Kessler, and Albino Tenge., 2016. Key Socioeconomic Factors influencing Sustainable Land Management Investments in the West Usambara Highlands, Tanzania, Land Use Policy, 51, 260-266.

Paudel, G.S., and Thapa, G.B., 2004. Impact of social, institutional and ecological factors on land management 
practices in mountain watersheds of Nepal, Appl. Geogr. 24, 35-55.

Payne, G., 2002. Land Rights, and Innovation: Improving Tenure Security for the Urban Poor, ITDG, London.

Rudiarto, I., 2006. Land Tenure \& Tenure Security Dalam Pemanfaatan Lahan Permukiman Kota (Permasalahan, Konsep Pendekatan dan Manfaat), J. Tata Loka, Vol 8, Undip Semarang.

Sanoff, Henry., 2000. Community Participation Methods in Design and Planning, John Wiley $\&$ Sons Inc, Canada.

Stewart, J. M., \& Sinclair, A. J., 2007. Meaningful Public Participation in Environmental Assessment: Perspectives from Canadian Participants, Proponents, and Government; Journal of Environmental Assessment Policy and Management, 9 (2). Retrieved from http://www.worldscientific.com/doi/pdf/10.1142/S14643 33207002743.

Tenge, A.J., De Graaff, J., Hella, J.P., 2004. Social and economic factors affecting the adoption of soil and water conservation in West Usambara highlands", Tanzania. Journal Land Degrad. Dev. 15, 99-114.

-, 2018. Pengurangan Resiko Bencana Berbasis Komunitas, Program Global Resilience Partnership Transform, Dinas Pekerjaan Umum Kabupaten Semarang dan $\mathrm{MCl}$.

---- 2014. Integrated Climate Change Strategy Semarang Regency Strategi Year 2015-2020, Semarang Regency Government, BLH.

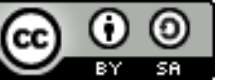

C 2019 Journal of Geoscience, Engineering Environment and Technology. All rights reserved. This is an open access article distributed under the terms of the CC BY-SA License (http://creativecommons.org/licenses/by-sa/4.0/). 